\title{
Demystifying the local: Considerations for higher education engagement with community food systems
}

\author{
Howard Rosing ${ }^{a}$, DePaul University
}

Submitted 14 December 2011 / Revised 21 February 2012 / Accepted 13 July 2012 / Published online 15 August 2012

Citation: Rosing, H. (2012). Demystifying the local: Considerations for higher education engagement with

community food systems. Journal of Agriculture, Food Systems, and Community Development, 2(4), 79-84.

http://dx.doi.org/10.5304/jafscd.2012.024.005

Copyright (C) 2012 by New Leaf Associates, Inc.

\begin{abstract}
Many universities and colleges have started to channel resources toward understanding and supporting small-scale food systems development in low-income communities. These efforts are often embedded into institutional sustainability initiatives that incorporate new curricula, research agendas, and community engagement. Students, staff, and faculty increasingly engage in community-based research, service-learning opportunities, internships, practicum and/or pro bono technical assistance in support of local food projects. These forms of engagement frequently operate in urban sectors where access to fresh food is challenged, for example, by historical patterns of

Author note: This commentary draws on data from initial findings of the Chicago Community Gardeners Study, a multiyear study of the role of higher education in supporting community gardens in Chicago.

a Howard Rosing, Irwin W. Steans Center for Communitybased Service Learning; DePaul University; 2233 North Kenmore, Chicago, Illinois 60614 USA: hrosing@,depaul.edu
\end{abstract}

racial segregation and social exclusion. Drawing on insights from ongoing anthropological research in Chicago on the role of higher education institutions in supporting community food systems development, this commentary presents a short set of considerations for higher education institutions that engage in local food projects within lowincome communities. The author suggests that prior to such engagement, academics more fully comprehend how communities perceive local and alternative food initiatives, and that higher education institutions formulate outreach initiatives that embed food systems development within a community development and social justice framework.

\section{Keywords}

community food systems, food deserts, community engagement, higher education

There has been an unprecedented shift in U.S. higher education toward interest in sustainable and community food systems. As part of this move- 
ment, many universities and colleges have channeled resources toward understanding and supporting small-scale food systems development (e.g., Raison, 2010). These efforts are often embedded into institutional sustainability initiatives that incorporate new curricula, research agendas, and community engagement (Barlett, 2010). Such initiatives are somewhat distinct from historical agricultural support provided by land-grant institutions with ties to corporate agribusiness. Students, staff, and faculty increasingly engage in communitybased research, service-learning opportunities, internships, practica, and pro bono technical assistance in support of local food projects in lowincome communities. These forms of engagement frequently operate in urban sectors where access to fresh food is challenged, for example, by historical patterns of racial segregation and social exclusion (Guthman, 2008, p. 432; Powell, Slater, Mirtcheva, Bao \& Chaloupka, 2007; Zenk, Schulz, Israel, James, Bao \& Wilson, 2005). The general premise of this movement in higher education is that locally produced food, distributed through local channels and consumed locally, is good for the health of residents, the natural environment and the economy of urban communities (Born \& Purcell, 2006) .

In this brief commentary, I present some considerations for higher education institutions that engage in local food systems development in low-income communities. These insights emerge from existing literature and preliminary observations drawn from ongoing anthropological research in Chicago on the role of higher education institutions in supporting community food systems development in underserved neighborhoods. In collaboration with several community partners in four neighborhoods, this research seeks to understand how universities can offer support for residents in their efforts to improve community and household food security. These efforts could include student, faculty, and staff assistance in a wide range of projects, including community and school gardens, container gardening programs, garden-based food aid, vocational training programs, and food advocacy campaigns. The research, which involves a neighborhood garden inventory, qualitative interviews with gardeners, and participant observation at community meetings, seeks to understand what higher education institutions can do to improve local food production among Chicago residents with the least wherewithal.

Discussions about food access in cities like Chicago almost invariably bring up the concept of food deserts. The concept has its origins in policy research and development discussions within the United Kingdom (Whelan, Wrigley, Warm \& Cannings, 2002). The food desert metaphor highlights areas of cities where residents depend on small stores with a paucity of fresh food. At first glance, Chicago offers a quintessential example of the U.S. food desert: vast sectors of the city without a supermarket, while corner stores dot those same sectors with packaged processed foods, sugary and/or alcoholic beverages, and limited quantity of fresh produce (Block, Chavez \& Birgen, 2008; Block \& Kouba, 2006; Gallagher, 2006; Gallagher, 2011). In 2006, a report entitled "Examining the impact of food deserts on public health in Chicago" on Chicago's food deserts was published (Gallagher, 2006). The report offers a bleak picture of food access in the city, with a food desert map graphically depicting access challenges in close to half the city. Interestingly, the Chicago food desert map is almost identical to the map published by the city of Chicago highlighting distribution of Black/African American residents across the city (City of Chicago, 2007). Comparing the two maps is a telling exercise in that it highlights racial segregation in the city in relation to the local food economy. Along with the predominantly white neighborhoods outside the deserts, one also sees that the majority of Latino neighborhoods are not deserts, further raising the question about what happened to the food economy in African American neighborhoods on the south and west sides of the city.

The Chicago food desert map presents larger questions about historical racial segregation and its negative impact on the economies in predominantly African Americans neighborhoods of U.S. cities. The departure of supermarkets from African American neighborhoods in the U.S. — what some authors have termed "supermarket redlining" (Eisenhauer, 2002) - is not a new phenomenon and one certainly not unique to Chicago. In many cities, residential and commercial redevelopment 
efforts lured supermarket chains into more affluent and generally whiter neighborhoods that are the product of municipal policies to spur so-called urban renewal. The concerns raised by food desert studies in Chicago have led policy-makers to establish incentives to lure supermarkets back into the deserted neighborhoods (Heinzmann, 2011; Spielman, 2011; Thomas, 2011). Chicago policymakers and advocates from the nonprofit sector have also argued for programs and incentives that encourage corner stores and corporate chain pharmacies to stock more fresh produce (Byrne, 2010; Valez, 2012). Others lobby hard for people to have access to the resources necessary to produce food locally, for example, in community gardens and urban farms (e.g., see auachicago.org or www.chicagofoodpolicy.org).

In proposing an urban agriculture ordinance, Chicago's mayor described it as "an important component of a comprehensive strategy to eliminate food deserts in Chicago while creating jobs" (Mayor's Press Office, 2011). The ordinance passed in September 2011. It is difficult to argue with the veracity of this proposal. Yet acceptance of alternative food practices in low-income African American communities, as Guthman (2008) suggests, may be a more complex issue and one sometimes driven by the desires of predominantly white institutions from outside the community. Since 2010, I have participated in discussions with community gardeners who are residents of a Chicago neighborhood deep in the core of Gallagher's 2006 food desert map. The gardeners meet monthly to talk about ways they would like to develop local food production in their neighborhood and to hear from experts in urban agriculture. The neighborhood was once inhabited by a predominantly white population supported by labor opportunities in the now languishing industrial and commercial economy. Presently, the population is 98 percent African American and has numerous economic and social challenges related to deindustrialization, housing foreclosures, and decline in commercial activity, including that of the retail food sector. Consequently, the neighborhood is spotted with vacant lots, including over 350 that are owned by the municipality. With varying degrees of environmental remediation, these could become community gardens or urban farms.

Though the city passed an ordinance legalizing the zoning of urban agriculture, the idea of using these vacant spaces for gardening or farming is not uniformly accepted by residents of the neighborhood. Opinions in the community range from those who are strictly against any kind of urban agriculture, to those concerned about outside groups seeking to extract profits from externally driven urban agriculture projects, to those who would like a clearer process for local residents to access land to grow food. From the gardeners' perspective, resistance to local food production is attributed to either alternative views about how vacant land should be developed, or, more importantly, to intimate historical connections between African Americans, agriculture, slavery, and sharecropping. Essentially, there is a sense that urban agriculture incites painful memories of life in the South left behind by mid-twentieth century migration to northern cities. Gardeners have shared stories about how some residents have fought politically against access to vacant lots by gardeners. For example, they've cited challenges by neighborhood associations to garden development on green space due to concerns about affecting the "aesthetics" of the neighborhood. Thus local food production does not appear to be uniformly accepted by all members of the community.

In addition to resistance to local food production from a segment of the community, gardeners display a considerable variety of motivations to engage in urban agriculture. Their comments suggest that food is frequently not even the primary rationale for creating community gardens. A central interest expressed by several gardeners, for example, is the role gardens play in community-building, education and youth development, and the potential for job creation, rather than simply as a food source. There is a general belief among gardeners that there needs to be more efforts on the part of the city government to create clearer paths to land access, remediation of soil, and reduced regulations on practices such as composting. Others express concern about how the school system has yet to take seriously efforts at integrating nutrition and food production into the curriculum and to link the latter with school gardens. In general, there is 
an underlying sentiment that food production contributes to resiliency of the community and that expanding food production needs to be understood as part of a response to broader community and economic development concerns.

Engagement with gardeners in Chicago's lowincome neighborhoods clearly involves entering a culturally complex and sometimes politically contentious context. Local universities and colleges in the city have always been intricately linked to the transformation of these contexts through their land and neighborhood development practices and local research projects. In more recent decades, civic and community engagement initiatives — including DePaul's many programs — involving students working with underserved populations are viewed as a key teaching strategy; faculty increasingly find ways to align their scholarship and teaching agendas with urban food access issues (Rosing, 2007; Rosing \& Hofman, 2010). Some authors have argued that such initiatives can be understood as part of a broader decline in state-sponsored social welfare, emphasizing local and volunteer solutions to community challenges (Hyatt, 2001; Petras, 1997). Others have suggested that local food systems development, especially when it is supported by volunteer labor, can be situated within a neoliberal agenda to deflect attention away from state responsibility for addressing broad social inequalities and toward micro-level neighborhood solutions that depend on support from outsiders, including universities (Guthman, 2008). In this regard, small-scale food projects align well with a shift in the U.S. political economy whereby social welfare functions and community development efforts are increasingly deferred to privately funded, nonprofit organizations and community and household-level solutions as a policy response to social inequality (Brenner \& Theodore, 2002).

Whether they choose to or not, higher education institutions cannot remain apolitical when they engage students and faculty in community-based food projects. Neighborhood food projects are embedded in residents' concerns about land use and community development efforts. Such initiatives may be viewed within low-income communities as another way that outside institutions, working in their own self-interest, seek to extract resources (student training and data) rather than contribute to positive community transformation. Thus, a larger question emerges as to how higher education institutions can support the rapidly expanding movement to create community food systems. In what ways can universities and colleges support sustainable community development that encourages investment in resident-designed projects that place food, health, education, and wellness at the center of economic development strategies (Williams, 2005, p. 124)? This question moves far beyond the notion that higher education can offer technical assistance to local food producers and distributors in low-income communities. Community food system initiatives would need to incorporate a more explicit social justice language and practice within higher education community outreach efforts. Engagement would have to expand beyond ameliorative support of local food projects into the realm of support for communitydriven collective action and food policy-making demanding that food production and distribution resources be a part of broader community development efforts (Block, Chávez, Allen, Ramirez, 2012).

Recognizably, a move toward a deeper political engagement in community development and local food justice movements might be difficult for many higher education institutions. It would require institutions to look critically at their own role in the local and regional food system both in the areas of research and institutional food procurement practices (Barlett, 2010, p. 105). As a starting point, however, the academy might consider the diverse ways that residents of low-income communities perceive local food initiatives. Initial observations in Chicago suggest that these projects are not uniformly accepted and that motivations for resident involvement vary considerably. Thus, community food projects in the city are always enmeshed in local politics in a way that is not readily apparent to higher education practitioners. By demystifying what local food initiatives mean within particular community settings, universities and colleges can more effectively design ways to channel institutional resources into communities in ways that support locally driven, positive transformation of the food system. 


\section{References}

Barlett, P. F. (2010). Campus sustainable food projects: Critique and engagement. American Anthropologist, 113(1), 101-115. http://dx.doi.org/10.1111/j.15481433.2010.01309.x

Block, D. R., Chávez, N., Allen, E., \& Ramirez, D., (2012). Food sovereignty, urban food access, and food activism: Contemplating the connections through examples from Chicago. Agriculture and Human Values, 29(2), 203-215. http://dx.doi.org/10.1007/s10460-011-9336-8

Block, D., Chavez, N., \& Birgen J. (2008). Finding food in Chicago and the suburbs: The report of the Northeastern Illinois Community Food Security Assessment. Chicago: Chicago State University Frederick Blum Neighborhood Assistance Center. Retrieved from http://www.csu.edu/nac/documents/reportto thepublic060308.pdf

Block, D., \& Kouba, J. (2006). A comparison of the availability and affordability of a market basket in two communities in the Chicago area. Public Health Nutrition, 9(7), 837-845. http://dx.doi.org/10.1017/PHN2005924

Born, B., \& Purcell, M. (2006). Avoiding the local trap: Scale and food systems in planning research. Journal of Planning Education and Research, 26, 195-207. http://dx.doi.org/10.1177/0739456X06291389

Brenner, N., \& Theodore, N. (2002). Cities and the geographies of "actually existing neoliberalism." Antipode, 34, 349-379. http://dx.doi.org/10.1111/1467-8330.00246

Byrne, J. (2010, August 11). Chicago partners with Walgreens to bring groceries to food deserts. Chicago Tribune. Retrieved from http://articles.chicagotribune.com/2010-08-11/ business/ct-biz-0812-food-deserts-20100811 1 food-deserts-wal-mart-grocery-stores

City of Chicago (2007). Distribution of Black/African American Across City. Retrieved from http://www.cityofchicago.org/city/en/depts/doit/ supp info/census maps.html

Eisenhauer, E. (2002). In poor health: Supermarket redlining and urban nutrition. GeoJournal, 53(2), 125-133. http://dx.doi.org/10.1023/A:1015772503007

Gallagher, M. (2006). Examining the effect of food deserts on public health in Chicago. Chicago: Mari Gallagher Research and Consulting Group. Retrieved from http://marigallagher.com/projects/4/
Gallagher, M. (2011). The Chicago food desert progress report . Chicago: Mari Gallagher Research and Consulting Group. Retrieved from http://marigallagher. $\mathrm{com} /$ site_media/dynamic/project_files/ FoodDesert2011.pdf

Guthman, J. (2008). Bringing good food to others: Investigating the subjects of alternative food practice. Cultural Geographies, 15, 431-447. http://dx.doi.org/10.1177/1474474008094315

Heinzmann, D. (2011, October 25). Emanuel steps up battle against city's "food deserts." Chicago Tribune. Retrieved from http://articles.chicagotribune.com/ 2011-10-25/news/ct-met-emanuel-food-desert20111025_1_food-deserts-mari-gallagher-stores-inunderserved-areas

Hyatt, S. B. (2001). From citizen to volunteer: Neoliberal governance and the erasure of poverty. In J. Goode \& J. Maskovsky (Eds.), New poverty studies: The ethnography of power, politics and impoverished people in the US (pp. 201-235). New York: New York University Press.

Mayor's Press Office (2011, July 28). Mayor Rahm Emanuel and Alderman Ameya Pawar introduce ordinance to support urban agriculture, create jobs, and expand access to fresh, healthy food across Chicago. Retrieved from http://www.cityofchicago. org/city/en/depts/mayor/press room/press relea ses/2011/july 2011/mayor rahm emanuelandalde rmanameyapawarintroduceordinancetosuppo.html

Petras, J. (1997). Volunteerism: The great deception. Economic and Political Weekely, 32(27), 1587-1589.

Powell, L. M., Slater, S., Mirtcheva, D., Bao, Y., \& Chaloupka, F. J. (2007). Food store availability and neighborhood characteristics in the United States. Preventive Medicine, 44(3),189-195. http://dx.doi.org/10.1016/j.ypmed.2006.08.008

Raison, B. (2010). Educators or facilitators? Clarifying Extension's role in the emerging local food systems movement. Journal of Extension, 48(3), 1-5.

Rosing, H. (2007). Food for more than thought: Coursebased action research on corners stores in Chicago. In N. G. Hofman \& H. Rosing (Eds), Pedagogies of praxis: course-based action research in the social sciences (pp. 1-20). Boston, Mass.: Anker Publishing Company.

Rosing, H., \& Hofman, N. G. (2010). Service learning and the development of multidisciplinary community-based research initiatives. Journal of Community Practice, 18, 213-232. http://dx.doi.org/10.1080/10705422.2010.490101 
Spielman, F. (2011, March 16). Daley announces plans to build two new South Side Wal-Marts. Chicago Sun Times. Retrieved from http://www.suntimes.com/ news/politics/4354003-418/daley-announces-twonew-wal-marts-suggests-opponents-had-racialmotives.html

Thomas, C. (2011, June 15). Emanuel meets with grocery chains to resolve "food deserts." ABC Local. Retrieved from http://abclocal.go.com/wls/story? section $=$ news $/$ local\&id $=8192924$

Velez, J.-P. (2012, February 11). How about a nice fresh orange to go with your Cheetos? The New York Times. Retrieved from http://www.nytimes.com/ 2012/02/12/us/program-aims-to- bring-freshproduce-and-meats-to-chicagos-so-called-fooddeserts.html
Williams, O. (2005). Food and justice: The critical link to healthy communities. In D. N. Pellow \& R. J. Brulle (Eds.), Power, justice, and the environment: $A$ critical appraisal of the environmental justice movement. (pp. 118-130). Cambridge, Mass.: Massachusetts Institute of Technology.

Whelan, A., Wrigley, N., Warm, D., \& Cannings, E. (2002). Life in a "food desert." Urban Studies, 39(11), 2083-2100.

http://dx.doi.org/10.1080/0042098022000011371

Zenk, S. N., Schulz, A. J., Israel, B. A., James, S. A., Bao, S., \& Wilson, M. L. (2005). Neighborhood racial composition, neighborhood poverty, and the spatial accessibility of supermarkets in metropolitan Detroit. American Journal of Public Health, 95(4), 660667. http://dx.doi.org/10.2105/AJPH.2004.042150 